\title{
Albanian Communist Prisons and the Will to Survive, as Narrated in the Documentary Novel "Live Only to Tell", By Father Zef Pllumi
}

\author{
1,2 Eljon Doçe, Erenestina Gjergji Halili \\ 1,2 Department of Literature, University of Tirana, Rr. e Elbasanit, Tirana, Albania
}

\begin{abstract}
"To those who died as humans, to those who stood as humans during those hard times where the humans were transformed into working animals"
\end{abstract}

Father Zef Pllumi, "Live only to tell"

Soon after the fall of communism in Albania, the Albanians, especially those who were subjected to the immense violence and oppression from that political system, felt the urge to tell their stories.

For some of them, that wasn't just something that was done because they wanted to be famous or important in the eyes of the world, but they wanted to inform everyone on what really happened during that dark period of Albania's history.

On the other hand this was also a way to confront themselves with their sad past as a need they had to survive again in the new reality after the communism collapsed.

Religion was severely attacked during Albanian communism. In 1967 Albanian communist regime proclaimed Albania as an "atheist state" and everyone who was part of religious institutions had only two choices: that person either had to abandon his faith and in as lot of cases he had to do this disconnection with his religion in public, as an propagandistic way to make the others, either his colleagues or the believers, to follow his example and this was somehow the "easy" way; or he could choose to face the situation, to not accept to do this forced choice and this would mean only one thing: the beginning of living a hell on earth until their last breath. 
This choice would mean imprisonment, physical and psychological tortures beyond imagination and total deprivation from the basic human rights. Living in those extreme conditions gives us the "perfect" example of the literal meaning of the word "survival"

Father Zef Pllumi, is one of the few priests who managed to stay alive for about three decades in different prisons around Albania. He was convicted as a political prisoner with the only "fault" that he was a priest and that he didn't admitted to abandon his devotion to God.

After spending more than a quarter of a century in Albanian communist prisons he was released in 1990, at the time when the regime was falling apart.

In 1995 was published the first part of his trilogy "Live only to tell", by Father Zef Pllumi, which was one of the few survivors of the communist prisons and one of the most important intellectuals who brought maybe the most complete data that Albanian history has in the respect of communist period.

This type of history we are talking about is not an academic history, it is the narration of a personal story, it is the story of Father Zef Pllumi itself and at the same time it is the story of all those people who refused to submit their freedom of thinking and being different to the regime.

This book is a personal testimony as well as a collective testimony of the people who were imprisoned, also it is the story of all the other Albanians who maybe were not in an penitentiary institution called prison but, in fact, they were also deprived from a lot of basic rights and they just had the illusion of being free while they were actually living in a larger scale prison called Albania.

"Live only to tell" (In Albanian "Rrno vetëm për me tregue") is written in a documentary novel style which means that in one hand this work can be read as a factual history book and on the other hand, without losing the dimension of the historical truth, the experience of reading this type of history is not the same as reading just a bunch of facts, dates, names or events.

This special type of prose offers to the reader the emotional feeling of reading a fictional book but with real facts and episodes.

Despite the title of the book, Father Zef Pllumi did not wanted "only to tell" what happened in communism but in this novel. He also wants to narrate everything in a way so it can't be forgotten from the reader and this is why his history is a personal history, full of emotions and not only an assemblage of cold historical facts.

Probably Father Zef Pllumi would not have been the one we know today from the testimony that he has left behind, if he had not been so strongly tested through his long years of prison. Evidently, the deep spiritual peace and the great lucidity of reasoning which is felt while reading "Live only to tell" would have never been the same unless he was tested through the fire of suffering. 
Dante Alighieri had to go down to Hell prior to go to Paradise and Odysseus had to fight with the monsters before he could to return at his home, in Ithaca.

It seems that there is an universal paradigm in the way things work: there is no easy way out to find the real self and in some cases this way is very hard to be undertaken, but it is the only way.

Father Zef Pllumi made the decision and chose, with his free will, to make the same Dantesque journey through the communist prisons, from an horror to another horror, year after year, until one day he had the opportunity to write his memories an whole the experience he had and to share it with the others so everyone could understand what Albanian communism really was.

However, his journey was not as parabolic as that of Dante or as fabulous as that of Odysseus. Father Zef Pllumi made a journey of flesh and blood, through a terrestrial hell, filled with horrors no less shocking than the Dante's or Homeric scenes. Today we can also see this Franciscan priest journey, who was blamelessly sentenced (same like Jesus Christ) as an allegory, same like the allegories of Dante and Homer: as the allegory of seeking a new "Paradise" or a new "Itaca", in other words, seeking the personal spiritual peace and the fulfillment of his religious tasks

In this particular type of prose, the place that almost the whole story talks about, in the majority part of the novel, is the space of communist prisons. On the other hand, within this place, in the conditions of the violence and the extreme oppression of the fundamental human rights, Father Zef Pllumi creates, however, an inner dimension of freedom, which is a state of mind of considering somehow being free and creating this new reality inside the cells of the prison. Through this way of thinking he proves exactly the idea that freedom to exist and to think is an indestructible personal right and that it cannot be annihilated even through limitations, constraints or even physical violence.

The survival of Father Zef Pllumi is not limited only in the physical survival because if it was just that, he would not made the choice to pursue his religious and spiritual vocation when he had obvious consequences for this choice. He understands survival as an effort and resistance of being free.

Despite appearing as a tale that speaks about prison, no matter how paradoxical it may seem, "Live only to tell" actually talks about freedom. In all the meanings of the word "prison" there is not a single connotation that gives a positive feeling, but if we read this book with the right attention "Live only to tell", we would see that Father Zef Pllumi is spiritually a completely free man. He lives out of the physical situation where he is and in his mind he tries to create small pieces of freedom to survive. For example, we can se these little spaces of freedom when he tries to create a garden of flowers in the prison camp; when he becomes friends with a toad that he takes care of it every day to feed him and shed tears when he learns that the toad has been poisoned during a disinfection process in the prison; when the cats return to the beloved friends of the inmates and when the presence of the mice's is not as terrible when as you are in 
the isolation room and when only the presence of another living being keeps alive the hope that you will survive another day.

Father Zef Pllumi has an impressive desire to create, no matter what. He wants to create even in the conditions when he faces with infectious diseases or epidemics that were present in the prison camp and when the prisoners use to die every day; he wants to create despite of gangrenous wounds, malnutrition, worms infected water which should be drunk when the thirst could cause death from the dehydration.

The immense joy that he has when he had to fix an old writing machine, to build tools, or the desire to make new friends in any prison where he went, was certainly a form of physical survival and a way to maintain the mental balance that, in that situation, was a nearly impossible mission.

Father Zef Pllumi creates a new "place" to set his existence to escape from that physical state which he could not change. This new reality is in its mental state which rejects what is happening.

This might be exactly the case that supports the concept that there is no really an "objective" reality and that everything is a matter of perception and choice.

On the other hand, his steadfast resistance to faith makes him to see every moment of suffering as a new step that brings him closer to his Creator. In his mind and thoughts is clear the idea that the suffering of the flesh cannot destroy the human soul.

He accepts to "hold his cross" and from this Christian perspective, of all the situations like being under physical tortures or mental pressure, are faced under this divine light, which enables the creation of this new spiritual level of existence that overcomes the physical one.

In Matthew's Gospel (Matthew 4: 1-11), it is said that Jesus Christ was brought into the wilderness by the Holy Spirit himself to be tempted by the Devil by allowing him to fast for 40 days and that His human nature had Jesus was quite hungry. When the Devil saw this human weakness, the hunger, the pain of the flesh, thought to benefit to overcome Christ by remembering His omnipotent divine nature and telling him that Christ could easily turn stones into bread, but the Son of God and Man at the same time responds: It is written that man does not live only by bread but by every word that comes from God's mouth. (Matthew 4: 4, The Bible, New Testament) We believe that Father Zef Pllumi, as a son of Man, and as a man of God, has internalized this gospel and that was the reason why he survived in his long years of suffering.

Keywords: communism; documentary prose; freedom; prison; testimony 
Bibliography:

1. 2. Át Zef Pllumi, "Rno vetëm për me tregue”, (Ribotim), Tiranë, "55”, 2006.

2. Bibla, Diodati i Ri

3. Sabri Hamiti, “Át Zef Pllumi”, Botime Françeskane, Shkodër, 2018. 